http://dx.doi.org/10.18778/1509-877X.2018.04.04

\title{
ODPOWIEDZIALNOŚĆ OSÓB TRZECICH ORAZ NASTĘPTWO PRAWNE W OBECNIE OBOWIĄZUJĄCEJ ORDYNACJI PODATKOWEJ I PROJEKCIE NOWEJ ORDYNACJI PODATKOWEJ ZARYS PROBLEMATYKI
}

\begin{abstract}
Streszczenie. Zasadniczym celem artykułu jest wykazanie różnic w uregulowaniu pozycji prawnej osób trzecich oraz następców prawnych na gruncie obowiązującej ustawy - Ordynacja podatkowa oraz projektu Nowej Ordynacji podatkowej. Celem ubocznym jest wskazanie wad i błędów w uregulowaniu tych zagadnień na gruncie obowiązującej ustawy - Ordynacja podatkowa.

W opracowaniu jako metodę badawczą zastosowano krytyczną analizę przepisów art. 107-118 ustawy - Ordynacja podatkowa oraz art. 249-273 i art. 274-293 NOP. Wykazano wiele wad i błędów w uregulowaniu omawianych zagadnień na gruncie obowiązującej ustawy - Ordynacja podatkowa. Wskazano także, które z uregulowań projektu NOP mogą służyć do trafniejszej wykładni przepisów obowiązującej ustawy.

Słowa kluczowe: rażąco niesłuszna odpowiedzialność osoby trzeciej w NOP, przedawnienie zobowiązania osoby trzeciej w NOP, następstwo prawne osób prawnych i spółek osobowych w transgranicznym łączeniu się spółek kapitałowych i spółki komandytowo-akcyjnej w NOP, podmiotowy zakres następstwa prawnego w NOP, przedmiotowy zakres następstwa prawnego w NOP, decyzja w zakresie następstwa prawnego przedsiębiorstwa w spadku
\end{abstract}

* Doktor nauk prawnych, sędzia Naczelnego Sądu Administracyjnego, e-mail: babiarzstefan@gmail.com 
1. WPROWADZENIE

Wprawdzie Nowa Ordynacja podatkowa ${ }^{1}$ (NOP) jeszcze nie weszła w życie i co więcej - nie została nawet uchwalona przez Sejm $\mathrm{RP}^{2}$, to jednak podejmowane działania wskazują na to, że projekt NOP zostanie uchwalony i stanie się obowiązującym prawem.

Na wstępie należy zauważyć, że projekt NOP w omawianym zakresie uzyskał właściwą systematykę. I tak zagadnienie odpowiedzialności podatkowej osób trzecich zostało uregulowane w Dziale II w rozdziale 11, który składa się z dwóch oddziałów: 1. Przepisy ogólne, 2. Osoby trzecie i zakres ich odpowiedzialności. Z kolei przepisy o następstwie prawnym znalazły się w Dziale II rozdział 12. Następstwo prawne, który składa się także z dwóch oddziałów: 1. Następstwo prawne podmiotów przekształconych i 2. Następstwo prawne spadkobierców, zapisobierców windykacyjnych i przedsiębiorstwa w spadku. Taka systematyka porządkuje omawiane przepisy i umożliwia przez to ich prawidłową wykładnię.

\section{ODPOWIEDZIALNOŚĆ OSÓB TRZECICH}

W zakresie odpowiedzialności osób trzecich NOP utrzymuje w zasadzie obowiązujące dotąd regulacje, polegające na tym, że:

- katalog osób trzecich odpowiadających za zaległości podatkowe ma charakter zamknięty (art. $249 \$ 1 \mathrm{NOP}$ );

- odpowiedzialność osoby trzeciej ma charakter odpowiedzialności solidarnej z podatnikiem (względnie jego następcą prawnym, gdy zaległość podatkowa została przez niego przejęta), z wyjątkiem odnoszącym się do art. $257 \$ 2$ NOP, gdy przedsiębiorstwo lub jego zorganizowana część

1 Projekt ustawy - Ordynacja podatkowa przyjęty przez rząd 27 maja 2019 r. (skierowany do sejmu 4 czerwca 2019 r.), dostępny na stronie BIP Rady Ministrów - projekty ustaw przesłane do Sejmu RP.

${ }^{2} \mathrm{~W}$ sejmie odbyło się pierwsze czytanie projektu ustawy - Ordynacja podatkowa (druk nr 3517/VIII kadencja), projektu ustawy o Rzeczniku Praw Podatnika (druk nr 3516/VIII kadencja) i projektu ustawy - Przepisy wprowadzające ustawę - Ordynacja podatkowa i ustawę o Rzeczniku Praw Podatnika (druk nr 3518/VIII kadencja) w dniu 3 lipca 2019 r. W jego wyniku projekty ustaw zostały skierowane do Komisji Finansów Publicznych, która na swym posiedzeniu w dniu 4 lipca 2019 r. skierowała je do podkomisji stałej. Od 17 lipca 2019 r. trwała dyskusja nad harmonogramem prac. Równocześnie projekty skierowano do Biura Analiz Sejmowych w celu opracowania opinii, zakreślając miesięczny termin jej sporządzenia. 
zostały nabyte na współwłasność ułamkową, gdyż wtedy ta odpowiedzialność jest odpowiedzialnością w częściach ułamkowych;

- utrzymano dotychczasowy przedmiotowy zakres odpowiedzialności osób trzecich (art. $249 \$ 1$ NOP), z tym że modyfikacja tego zakresu może nastąpić w przepisie szczególnym (np. art. 261, art. 262 NOP ograniczają tę odpowiedzialność tylko do zaległości podatkowych).

Jednakże w art. $249 \$ 2$ NOP wprowadzono przepis umożliwiający elastyczne orzekanie o tej odpowiedzialności w sytuacji, gdy osoba trzecia udowodni lub uprawdopodobni, że byłoby to rażąco niesłuszne. Pomijając tu błędne sformułowanie „udowodni lub uprawdopodobni” (dodane do projektu już po przekazaniu projektu ustawy NOP Ministrowi Finansów), pojęcie to jest typowym określeniem nieostrym, jakich wiele w systemie prawa podatkowego. Określenie to w założeniu ma zapewnić elastyczność orzekania w przypadku, gdy przepisy prawa regulujące dane kwestie są restrykcyjne. Wymagają one zgodnie z przyjętymi w orzecznictwie ${ }^{3}$ i piśmiennictwie $e^{4}$ poglądami uwzględnienia nie tylko uwarunkowań zewnętrznych wynikających z chronionych wartości zawartych w całym systemie prawa (Konstytucji Rzeczypospolitej), ale i jego uwarunkowań wynikających $\mathrm{z}$ wartości i zasad leżących u podstaw aktu normatywnego, w którym to pojęcie zastosowano. Oznacza to konieczność uwzględnienia zasad ogólnych prawa podatkowego (art. 14-32 NOP). Komisja nie zdecydowała się na przyjęcie uwag, wniosków i sugestii, by pojęcie to zdefiniować choćby przykładowo, właśnie z powodu koniecznego do uwzględnienia w konkretnej sprawie zakresu uwarunkowań zarówno wewnętrznych, jak i zewnętrznych danego aktu.

Poza tym utrzymano:

- zasadę, że o odpowiedzialności osoby trzeciej orzeka się w drodze decyzji (art. $251 \$ 1$ NOP);

- katalog przesłanek negatywnych wskazujący na to, kiedy nie może być wszczęte postępowanie podatkowe w sprawie odpowiedzialności osoby trzeciej, i jest on w zasadzie identyczny z obowiązującym dotąd, z tym że dodano jeszcze (art. $251 \$ 2$ pkt 2 lit. c) decyzję o zakresie odpowiedzialności spadkobierców lub zapisobierców windykacyjnych;

3 Zob. wyrok Naczelnego Sądu Administracyjnego (NSA) z dnia 20 listopada 1990 r., sygn. II SA 759/90, OSP 1991, nr 7-8, poz. 178.

4 Zob. W. Masewicz, Glosa do wyroku NSA z dnia 20 listopada 1990 r., II SA 759/90, OSP 1991, nr 7-8, poz. 178; L. Garlicki, Przegląd orzecznictwa TK, „Przegląd Sądowy” 1992, nr 11-12, s. 52. 
- zasadę, że odpowiedzialność osoby trzeciej jest odpowiedzialnością posiłkową i obowiązkiem organu jest prowadzenie tego postępowania w każdym przypadku (art. $251 \$ 2$ NOP), w stosunku do każdej osoby trzeciej;

- odrębne od ogólnych zasady przedawnienia wymiaru i poboru zobowiązania osoby trzeciej (art. 254-255 NOP).

Przepisy odnoszące się do przedawnienia zobowiązania osoby trzeciej w zakresie odpowiadającym obecnej treści art. 118 Ordynacji podatkowej ${ }^{5}$ zostały utrzymane. Natomiast zmiana dotyczy przepisu wprowadzonego w NOP, a mianowicie art. 255 dotyczącego przedawnienia poboru zobowiązania wynikającego z decyzji o odpowiedzialności osoby trzeciej. Przedawnienie poboru nastąpi z upływem 3 lat, licząc od dnia, w którym decyzja o odpowiedzialności osoby trzeciej stała się ostateczna.

Regulacja zawarta w art. 254 NOP odnosząca się do skutków prawnych wynikających z doręczenia decyzji o odpowiedzialności osoby trzeciej w zakresie zachowania terminu przedawnienia nawiązuje do ukształtowanego na gruncie art. $118 \$ 1$ o.p. rozwiązania usuwającego wątpliwości co do kwestii, czy upływ przewidzianego w nim terminu wiązać należy z decyzją pierwszej czy drugiej instancji ${ }^{6}$. Przyjęto jednak, że chodzi nie o jej wydanie - jak dotychczas - lecz doręczenie.

Katalog osób trzecich odpowiedzialnych za zaległości podatkowe w zasadzie nie uległ zmianie. Jednakże z jednej strony wykreślono obowiązujący obecnie art. 111 o.p. jako mający niewielkie praktyczne zastosowanie, a dodano art. 273 NOP odnoszący się do odpowiedzialności zapisobiercy zwykłego jako osoby trzeciej. Poza tym, co charakterystyczne, zakres przedmiotowy odpowiedzialności zapisobiercy został określony ściśle i obejmuje ona: zaległości podatkowe, podatek niepobrany lub pobrany, ale niewpłacony przez płatnika, podatek pobrany, ale niewpłacony przez inkasenta, odsetki za zwłokę naliczone do dnia wydania decyzji o odpowiedzialności osoby trzeciej od należności określonych wcześniej, a także odsetki od nieuregulowanych w terminie zaliczek na podatek, koszty upomnienia i koszty egzekucyjne powstałe do dnia wydania decyzji o odpowiedzialności osoby trzeciej.

Niektóre przepisy z tego zakresu zostały poprawione w sensie redakcyjnym (np. w zakresie określenia, że chodzi o wartość rynkową w art. 257 $\$ 3$, art. 259 \$2) czy poprzez objęcie odpowiedzialnością nie tylko

5 Ustawa z dnia 29 sierpnia 1997 r. - Ordynacja podatkowa (tekst jedn. Dz.U. z 2019 r., poz. 900 ze zm.), dalej: o.p.

${ }^{6}$ Zob. np. wyrok NSA z dnia 1 lutego 2017 r., sygn. II FSK 3638/14, CBOSA. 
dzierżawcy lub użytkownika (art. 114a o.p.), ale i najemcy, leasingobiorcy (art. 262 NOP). Zmiany redakcyjne objęły też art. 116 o.p. w odniesieniu do użytego w nim określenia „po likwidacji”, niejasnego terminologicznie (art. 264 NOP). Dotyczy to również uporządkowania terminologicznego art. 116a o.p. (art. 265 i 266 NOP).

Zaproponowano też odpowiedzialność wspólników zagranicznej spółki osobowej za jej zaległości podatkowe (art. $263 \$ 7$ NOP), a także odpowiedzialność członków organu zarządzającego za zaległości osoby prawnej zagranicznej (art. 265 NOP). Zagadnienia te nie są obecnie ujęte wprost w ustawie - Ordynacja podatkowa, co powoduje problemy w zakresie objęcia tych podmiotów odpowiedzialnością podatkową ${ }^{7}$.

\section{NASTĘPSTWO PRAWNE PODMIOTÓW PRZEKSZTAŁCONYCH}

Przez następstwo prawne rozumieć należy przejście praw i obowiązków z jednego podmiotu na drugi. Chodzi oczywiście o następstwo prawne pochodne (sukcesję), tzw. translatywne, mocą którego dane prawo przechodzi w całości na dany podmiot, co nie zawsze jest regułą, np. w przypadku uregulowanym w art. 93c o.p. (art. 277 NOP), gdzie następstwo prawne następuje tylko w przypadku, gdy majątek osoby prawnej dzielonej stanowi zorganizowaną część przedsiębiorstwa. W przeciwnym wypadku mamy do czynienia z solidarną odpowiedzialnością osób trzecich (art. $117 \$ 1$ o.p. i art. $268 \$ 1 \mathrm{NOP}$ ). Nowa Ordynacja podatkowa w zakresie następstwa prawnego podmiotów przekształconych w zasadzie utrzymuje stan dotychczasowy. Trudno bowiem tu coś dodać albo ująć, skoro obowiązuje zasada, że następstwo prawne w prawie podatkowym kształtują przepisy ustrojowe. A Komisja Kodyfikacyjna nie była uprawniona do rozszerzenia tego katalogu, bo musiałaby zmieniać przepisy ustrojowe. Nowym rozwiązaniem jest tu art. $274 \$ 3$ NOP odnoszący się do odpowiedniego stosowania przepisów o następstwie prawnym osób prawnych i spółek osobowych do transgranicznego łączenia się spółek kapitałowych i spółki komandytowo-akcyjnej.

7 Zob. wyrok NSA z dnia 18 grudnia 2018 r., sygn. II FSK 2180/18, CBOSA; wyrok NSA z dnia 25 kwietnia 2017 r., sygn. I FSK 1665/15, LEX nr 2294072, z glosą krytyczną P. Suchockiego, „Prawo Podatkowe” 2019, nr 3, s. 46-53. Zob. też J. Kruczalak-Jankowska, Wpływ europeizacji prawa na instytucje prawa handlowego, Warszawa 2013, s. 130; M. Białkowski, Mobilność spółek w systemie prawa handlowego, "Zarządzanie i Finanse" 2012, t. 1, nr 2, s. 595-604. 
Zmiany zawarte w art. 274-283 NOP to zmiany o charakterze w istocie dostosowawczym, redakcyjnym, aktualizującym. Nowym przepisem jest w istotnej części art. 278 NOP (art. $97 \$ 4$ o.p.) odnoszący się do następstwa prawnego wynikającego $\mathrm{z}$ zastosowania się przez podmiot przekształcany nie tylko do praw i obowiązków wynikających z decyzji, ale też do praw i obowiązków wynikających z interpretacji ogólnych, objaśnień podatkowych (art. $545 \$ 1$ pkt $1 \mathrm{NOP}$ ), informacji ogólnych i interpretacji indywidualnych (art. $545 \$ 1$ pkt 2 i art. $558 \$ 1$ NOP) oraz utrwalonej praktyki interpretacyjnej organów podatkowych (art. 579 $\$ 1$ pkt 2 i art. $579 \$ 2$ NOP). Wówczas następuje wstąpienie w sytuację prawną ukształtowaną tym zachowaniem i objęcie ochroną prawną podmiotu przekształconego. Te zachowania dają mu ochronę prawną. Pojęcie podmiot przekształcany (przekształcony) na gruncie art. 278 NOP należy rozumieć w sposób obejmujący wszelkie formy następstwa prawnego uregulowane w rozdziale 12 . Z porównania art. 93d o.p. i przepisów NOP wynika, że zakres przedmiotowy następstwa w tych przypadkach NOP rozszerza na prawa i obowiązki wynikające $z$ decyzji wydanych na podstawie przepisów prawa podatkowego, z zastosowania się przez podmiot przekształcany do interpretacji ogólnych i objaśnień podatkowych, o których mowa w art. $545 \$ 1$ pkt 1 NOP, informacji ogólnych i interpretacji indywidualnych, o których mowa odpowiednio w art. $545 \$ 1$ pkt 2 i art. $558 \$ 1$ NOP, a także utrwalonej praktyki interpretacyjnej organów podatkowych, o której mowa w art. $579 \$ 1$ pkt 2 i w art. 579 $\$ 2$ NOP. W tych kwestiach stosuje się odpowiednio uregulowania zawarte w art. 274-277 NOP.

Zakres następstwa prawnego w odniesieniu do interpretacji ogólnych indywidualnych objaśnień podatkowych, informacji ogólnych oraz utrwalonej praktyki interpretacyjnej został dostosowany do orzecznictwa Naczelnego Sądu Administracyjnego.

Oznacza to, że jeżeli poprzednik prawny następcy prawnego nie skorzystał z ochrony wynikającej z interpretacji, bo się do niej nie zastosował, to następca, chcąc być objęty ochroną prawną, musi sam wystąpić o wydanie interpretacji albo zastosować się do objaśnień podatkowych, informacji ogólnych, interpretacji ogólnej czy utrwalonej praktyki interpretacyjnej organów podatkowych na zasadach ogólnych, ale ta ochrona będzie działała od chwili zastosowania się przez niego do tych praw i obowiązków. W przypadku zaś gdy zastosował się do tych instytucji prawnych poprzednik prawny, ochrona będzie kontynuowana. 
Ponadto zmiana dotyczy wprowadzenia przepisów o transgranicznym łączeniu się spółek kapitałowych i spółki komandytowo-akcyjnej (art. 270 $\$ 3$ NOP) oraz o transgranicznym podziale spółek (art. $273 \$ 2$ NOP). Przepisów w tym zakresie wprost wyrażonych nie było w treści ustawy - Ordynacja podatkowa.

\section{NASTĘPSTWO PRAWNE SPADKOBIERCÓW, ZAPISOBIERCÓW} WINDYKACYJNYCH I PRZEDSIĘBIORSTWA W SPADKU

W zakresie tej regulacji zmiany są istotne. Najogólniej rzecz biorąc, zmiany dotyczą:

a) zakresu podmiotowego następstwa prawnego:

- wprowadza się nową kategorię następcy prawnego, a mianowicie zapisobiercę windykacyjnego,

- wykreśla się z kategorii następców prawnych zapisobiercę zwykłego i przenosi się go do kategorii osób trzecich ze względu na małą praktyczną przydatność tego podmiotu wśród następców prawnych i ograniczoną możliwość zastosowania przepisu art. 106 o.p., tym bardziej że i tak zapisobierca zwykły był ograniczony w następstwie prawnym tylko do odpowiedzialności za zobowiązania podatkowe i inne należności wskazane w art. 98 o.p.,

- utrzymuje się jako następcę prawnego przedsiębiorstwo w spadku,

- wyeliminowano niejasną dotychczasową regulację odnoszącą się do braku następstwa prawnego spadkobierców po spadkobiercach (dalszy spadkobierca) i nabywcy spadku po spadkodawcy (art. $284 \$ 3$ NOP). Wyjątek dla dalszych spadkobierców został uczyniony w art. 293 NOP,

- spadkobiercy podatnika, płatnika, inkasenta i zapisobiercy windykacyjni będą następcami przejmującymi wszelkie prawa (art. $284 \$ 1 \mathrm{NOP}$ ) poprzednika prawnego oraz ściśle określone obowiązki (art. 283 NOP i art. 98 o.p.); tak określonego w sposób jasny uregulowania brak w obowiązującej ustawie;

b) zakresu przedmiotowego następstwa prawnego:

- zapisobierca windykacyjny (art. $284 \$ 4$ NOP) będzie następcą prawnym tylko wówczas, gdy przedmiotem zapisu windykacyjnego będzie przedsiębiorstwo (art. $55^{1}$ Kodeksu cywilnego $^{8}$ ).

W tym zakresie art. $981^{1} \$ 1$ k.c. stanowi, że w testamencie sporządzonym w formie aktu notarialnego spadkodawca może postanowić, że

8 Ustawa z dnia 23 kwietnia 1964 r. - Kodeks cywilny (Dz.U. z 1964 r., Nr 16, poz. 93 ze zm.), dalej: k.c. 
oznaczona osoba nabywa przedmiot zapisu z chwilą otwarcia spadku (zapis windykacyjny).

Trzeba tu zwrócić uwagę na zakres przedmiotowy zapisu windykacyjnego. Zgodnie $\mathrm{z}$ art. $981^{1}$ k.c. przedmiotem tego zapisu może być:

1) rzecz oznaczona co do tożsamości;

2) zbywalne prawo majątkowe;

3) przedsiębiorstwo lub gospodarstwo rolne;

4) ustanowienie na rzecz zapisobiercy użytkowania lub służebności.

Taka regulacja oznacza, że w przypadku pozostałych przedmiotów zapisu windykacyjnego (rzecz oznaczona co do tożsamości, zbywalne prawo majątkowe, gospodarstwo rolne, ustanowienie na rzecz zapisobiercy windykacyjnego użytkowania lub służebności) przedmiotowy i podmiotowy zakres następstwa prawnego przejdzie na spadkobierców;

- wyeliminowano budzący wątpliwości i spory podział praw i obowiązków na majątkowe i niemajątkowe, ale nie do końca (art. $97 \$ 2$ i 2a o.p. oraz art. $284 \$ 5$ i 6 NOP),

- wyeliminowano z zakresu przedmiotowego, budzące spory i dotąd uregulowane niejasno, przejęcie przez spadkobierców obowiązku podatkowego w pełnym zakresie, $\mathrm{z}$ wyjątkiem spadkobierców i zapisobiercy windykacyjnego oraz przedsiębiorstwa w spadku kontynuujących działalność gospodarczą spadkodawcy (art. $284 ₫ 5 \mathrm{NOP}$ ),

- uregulowano w sposób jasny, że spadkobierca niekontynuujący działalności gospodarczej spadkodawcy i spadkobierca spadkodawcy nieprowadzącego działalności gospodarczej nie przejmują przewidzianych w przepisach prawa podatkowego obowiązków niemajątkowych tych spadkodawców;

- wskazano, że przedmiotowym zakresem następstwa prawnego spadkobierców i zapisobierców windykacyjnych są co do zasady wszelkie prawa i ściśle określone obowiązki (art. $284 \$ 1$ NOP).

Określenie „wszelkie prawa” nie pozostawia wątpliwości, że jego zakresem są objęte także ekspektatywy nabycia praw, a więc i kontynuacja ulg podatkowych (zwolnień też - art. 3 pkt $20 \mathrm{NOP})^{9}$;

- ujednolicono zakres przejmowanych praw i obowiązków wynikających z zastosowania się przez podatnika, płatnika, inkasenta do praw i obowiązków wynikających z:

- decyzji organów podatkowych,

- interpretacji ogólnych,

- interpretacji indywidualnych,

9 Szerzej na ten temat zob. uzasadnienie do projektu NOP, s. 315-317. 
- informacji ogólnych,

- utrwalonej praktyki interpretacyjnej organów podatkowych (art. 284 $\$ 7$ NOP);

- zdefiniowano (definicja przykładowa) pojęcie „obowiązki niemajątkowe" (art. 284\$6 NOP),

- regulację zawartą obecnie w art. 100 o.p. (art. $288 \$ 1-4$ NOP) dostosowano do treści uchwały 7 sędziów NSA z dnia 23 maja 2016 r., sygn. II FPS 6/15, ONSAiWSA 2016, nr 5, poz. 72 (nie występuje zobowiązanie spadkobierców i zapisobierców windykacyjnych, ale tylko należności, których termin płatności wynosi 14 dni od dnia doręczenia decyzji). Ma to też związek z art. 101 o.p. (art. 289 NOP), a także z charakterem następstwa prawnego tych podmiotów, które wstępują z mocy prawa w prawa i obowiązki poprzednika prawnego, a jego zakres wynika z aktów deklaratoryjnych (postanowienie o stwierdzeniu nabycia spadku i jego zmiana czy uchylenie, akt poświadczenia dziedziczenia, europejskie poświadczenie spadkowe).

W art. $98 \$ 1$ o.p. (art. $287 \$ 1$ NOP) nie wpisano charakteru tej odpowiedzialności, a więc tego, czy ma ona charakter solidarny czy udziałowy. Otóż charakter tej odpowiedzialności wynika nie z przepisów obowiązującej ustawy - Ordynacja podatkowa i NOP, lecz z przepisów Kodeksu cywilnego, do których odsyła art. $98 \$ 1$ o.p. Są to przepisy art. 1012-1024 k.c. i art. $1030-1034^{1}$ k.c.

Utrzymano regulację dotyczącą zasad kontynuowania działalności gospodarczej przez spadkobierców i zapisobiercę windykacyjnego, tak jak to jest uregulowane w Ustawie z dnia 5 lipca 2018 r. o zarządzie sukcesyjnym przedsiębiorstwem osoby fizycznej ${ }^{10}$, wprost odsyłając do możliwości takiego ukształtowania kontynuowania działalności gospodarczej spadkodawcy. Tego w obecnej ustawie nie ma. Oznacza to, że ten tryb kontynuowania działalności gospodarczej spadkodawcy nie jest dla spadkobierców, zapisobierców windykacyjnych oraz osób wskazanych w art. 14 u.z.s. obligatoryjny.

W zakresie następstwa prawnego przedsiębiorstwa w spadku należy uwzględnić stosowne przepisy ustawy o zarządzie sukcesyjnym przedsiębiorstwem osoby fizycznej, tj. art. 13 i 14 u.z.s. Należy też brać pod uwagę, że małżonek przedsiębiorcy, jego spadkobiercy oraz zapisobiercy windykacyjni mogą kontynuować tę działalność przez jej osobiste prowadzenie na dotychczasowych zasadach.

10 Dz.U. z 2018 r., poz. 1629 ze zm., dalej: u.z.s. 
Ponadto poprawiono regulację odnoszącą się do kontynuowania działalności gospodarczej spadkodawcy przez zarządcę sukcesyjnego, wykreślając zbędne przepisy: art. $97 \$ 2$ a, art. 97a $\$ 3$ i 4 o.p.

Powstaje tu pytanie, kto powinien być adresatem decyzji z art. 285 NOP (art. 97a o.p.). Moim zdaniem należy tu uwzględnić nie tylko art. 7a o.p. (art. 59 NOP), z którego wynika, że następcą prawnym spadkodawcy jest przedsiębiorstwo w spadku, ale i treść art. 15 i 21 u.z.s. stanowiących, że osoby wskazane w art. 14 u.z.s. (małżonek przedsiębiorcy, któremu przysługuje udział w przedsiębiorstwie w spadku, lub spadkobierca ustawowy przedsiębiorcy, albo spadkobierca testamentowy przedsiębiorcy, albo zapisobierca windykacyjny, któremu zgodnie z ogłoszonym testamentem przysługuje udział w przedsiębiorstwie w spadku), oraz zarządca sukcesyjny działają w imieniu własnym na rachunek właściciela przedsiębiorstwa w spadku. To oznacza, że skoro zgodnie z art. 286 $\$ 1$ u.z.s. odpowiedzialność za zobowiązania podatkowe przedsiębiorstwa w spadku ponoszą zapisobierca windykacyjny kontynuujący prowadzenie tego przedsiębiorstwa, spadkobiercy zmarłego przedsiębiorcy, jeżeli nie został uczyniony zapis windykacyjny obejmujący przedsiębiorstwo w spadku, a także małżonek zmarłego przedsiębiorcy, któremu przysługuje udział w przedsiębiorstwie w spadku, to adresatem decyzji będą albo osoby wskazane w art.14 u.z.s., albo zarządca sukcesyjny (mający zdolność procesową i działający w imieniu własnym), a rozstrzygnięcie zawarte w decyzji wydawanej na podstawie art. 97a $\$ 1$ o.p. (art. 285 $\$ 1$ NOP) będzie się odnosiło do osób w tych przepisach wskazanych, a nie do przedsiębiorstwa w spadku, mimo że to ono jest zgodnie $\mathrm{z}$ art. 97 $\$ 1$ o.p. (art. $285 \$ 2 \mathrm{NOP}$ ) następcą prawnym. Dlaczego rozstrzygnięcie decyzji nie może się odnosić do przedsiębiorstwa w spadku? Moim zdaniem dlatego, że zarządca działa na rachunek tych podmiotów, o których mowa w art. 97a $\$ 1$ o.p. (art. $282 \$ 1$ NOP), a nie na rzecz przedsiębiorstwa w spadku (art. 15 i 21 u.z.s.).

Wprowadzone do art. 288 NOP odesłanie umożliwi zamknięcie luki $\mathrm{w}$ art. 97a o.p., ponieważ w nim nie określono terminu płatności należności.

Przepisy art. $289 \$ 1$ i art. $291 \$ 2$ i 3 NOP są konsekwencją zasady, że dalsi spadkobiercy spadkodawcy i nabywca spadku nie są następcami prawnymi spadkodawcy. To oznacza, że śmierć spadkobiercy spowoduje - w sytuacjach opisanych w tych przepisach - pomniejszenie zobowiązań podatkowych i tym samym przedmiotowego zakresu odpowiedzialności pozostałych spadkobierców. 
W przepisie art. 292 NOP (art. 103 o.p.) wprowadzono elastyczną klauzulę, że wyliczenie obowiązków informacyjnych ciążących na organie podatkowym jest wyliczeniem przykładowym.

Poza tym przepis art. 103 o.p. został w art. 292 NOP dostosowany do rozwiązań obowiązujących w NOP.

W art. $289 \$ 1$ i art. $291 \S 3$ NOP wprowadzono rozwiązania uniemożliwiające następstwo prawne $\mathrm{z}$ tytułu samej solidarnej odpowiedzialności i braku następstwa prawnego po spadkobiercach i w przypadku nabywcy spadku (art. $284 \$ 3$ NOP).

Przepis art. 293 NOP umożliwia ponadto otrzymanie nadpłaty i zwrotu podatku nie tylko spadkobiercom i zapisobiercy windykacyjnemu, ale i dalszym ich spadkobiercom.

\section{Podsumowanie}

Obowiązująca ustawa - Ordynacja podatkowa w zakresie regulowania zagadnień odpowiedzialności podatkowej osób trzecich, a także następstwa prawnego ma wiele wad. Dlatego też projekt Nowej Ordynacji podatkowej starał się te wady usunąć. Oczywiście, przyjęto tu zasadę utrzymania tych rozwiązań, które sprawdziły się w praktyce, jak: katalog osób trzecich, charakter odpowiedzialności osób trzecich, przedmiotowy zakres odpowiedzialności osób trzecich, zasady orzekania o tej odpowiedzialności czy przesłanki negatywne odpowiedzialności osób trzecich. W przypadku przepisów o następstwie prawnym podmiotów przekształconych utrzymano obecnie obowiązujący ich katalog choćby ze względu na zasadę, że następstwo prawne może być wykreowane tylko w przepisach ustrojowych. Znacznie szersza jest ingerencja w projekcie w odniesieniu do podmiotowego i przedmiotowego następstwa prawnego spadkobierców, zapisobierców windykacyjnych i przedsiębiorstwa w spadku. Wyeliminowano w zasadzie m.in. odpowiedzialność za obowiązek podatkowy, nabywca spadku nie będzie następcą prawnym spadkodawcy, solidarny charakter odpowiedzialności nie będzie kreował następstwa prawnego. Śmierć spadkobiercy w toku postępowania ustalającego zobowiązanie podatkowe spadkodawcy czy w toku postępowania o zakresie odpowiedzialności spadkobierców i zapisobierców windykacyjnych spowoduje zmniejszenie zakresu odpowiedzialności pozostałych spadkobierców, co wiąże się z tym, że dalsi spadkobiercy nie będą już następcami prawnymi spadkodawcy. 
Jednocześnie, jak się wydaje, przedstawiony rys porównawczy może być wykorzystany wraz z uzasadnieniem NOP do wykładni przepisów obowiązującej ustawy - Ordynacja podatkowa. Nowymi rozwiązaniami w NOP są z pewnością te, których nie ma w obowiązującej ustawie, a mianowicie możliwość nieodpowiadania osoby trzeciej za zaległości podatkowe w przypadku rażącej niesłuszności, w odniesieniu zaś do następstwa prawnego spadkobierców i zapisobierców windykacyjnych wyeliminowanie co do zasady objęcia jego przedmiotowym zakresem obowiązku podatkowego (w zasadzie), wyeliminowanie z zakresu podmiotowego następstwa prawnego dalszych spadkobierców i następcy spadku. W tym więc zakresie trudno mówić o możliwości wykorzystywania nowych rozwiązań w wykładni przepisów obowiązującej ustawy.

\section{BIBLIOGRAFIA}

Białkowski M., Mobilność spółek w systemie prawa handlowego, „Zarządzanie i Finanse” 2012, t. $1, \mathrm{nr} 2$.

Garlicki L., Przegląd orzecznictwa TK, „Przegląd Sądowy” 1992, nr 11-12.

Kruczalak-Jankowska J., Wptyw europeizacji prawa na instytucje prawa handlowego, Warszawa 2013.

Masewicz W., Glosa do wyroku NSA z dnia 20 listopada 1990 r., II SA 759/90, OSP 1991, nr 7-8. Suchocki P., Glosa do wyroku NSA z dnia 25 kwietnia 2017 r., I FSK 1665/15, „Prawo Podatkowe" 2019, nr 3.

\section{THIRD PARTY LIABILITY AND LEGAL SUCCESSION IN THE CURRENT Tax Ordinance Act and draft New Tax Ordinance Act OUTLINE OF THE ISSUES}

Summary. The main aim of the article is to demonstrate differences in the regulation of the legal position of third parties and legal successors on the basis of the current Tax Ordinance Act and the New Tax Ordinance draft. A side goal is to indicate defects and errors in regulation of these issues on the grounds of the current Act - Tax Ordinance.

The article uses as a research method a critical analysis of the provisions of Articles 107-118 of the Tax Ordinance Act and Articles 249-273 and 274-293 of the NOP. The text shows a number of flaws and errors in the regulation of the discussed issues on the grounds of the current Act - Tax Ordinance. It was also indicated which of the regulations of the New Tax Ordinance draft may serve for a more accurate interpretation of the provisions of the current act.

Keywords: grossly wrongful third party liability in New Ordinance Tax Act draft, statute of limitations for third party liability in New Ordinance Tax Act draft, legal entities and partnerships in cross-border mergers of capital companies and limited joint-stock partnership in New Ordinance Tax Act draft, personal scope of legal succession in New Ordinance Tax Act draft, subjective scope of legal succession in New Ordinance Tax Act draft, decision on legal succession of an enterprise inherited. 